\title{
FATIGUE ANALYSIS OF PULLEY BY USING FINITE ELEMENT ANALYSIS
}

\section{N. ANURADHA ${ }^{1}$, SUBRAMANYAM. B ${ }^{2}$, K. CHINNA MADDAIAH ${ }^{3}$, K. DEEPAK ${ }^{4} \&$ V. MAHIDAR REDDY ${ }^{5}$}

${ }^{1}$ Associate Professor, Department of Mechanical Engineering, MLR Institute of Technology, Hyderabad, Telangana, India

${ }^{2,3}$ Assistant Professor, Department of Mechanical Engineering, MLR Institute of Technology, Hyderabad, Telangana, India

${ }^{4}$ Professor, Department of Mechanical Engineering, Vardhaman College of Engineering, Hyderabad, India

${ }^{5}$ Assistant Professor, Mechanical Engineering Department, Institute of Aeronautical Engineering, Hyderabad, India

\section{ABSTRACT}

Conveyor pulleys deflect the belt on a conveyor and in the case of drive and take-up units, pulleys introduced the required motive force and tension into the belt. Mechanical advantage is a measurement of how much a simple machine multiplies a force. The bigger the mechanical advantage, the lesser the force needed, but greater the distance have to use that force.

The present analysis has been carried by using finite element analysis. By applying various identification numbers of the pulley and different RPMs, the analysis has been carried out for the same geometry of the material. KEYWORDS: Fatigue Analysis, Radial Stress, Hoop Stress, Von Mises Stress \& Analysis

Received: Nov 22, 2017; Accepted: Dec 13, 2017; Published: Dec 23, 2017; Paper Id.: IJMPERDFEB201811

\section{INTRODUCTION}

\section{MODELING OF WIND TURBINE BLADES}

The modeling of wind turbine blades has done as per the required geometry.

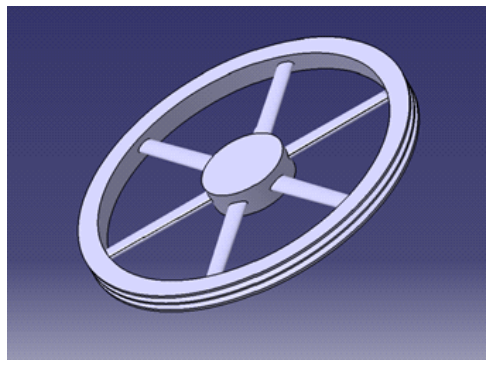

Figure 1: 3D Model of Pulley

\section{MATERIAL PROPERTIES \& LOAD CONDITIONS}

For the cast iron grade 20 material, the following material properties have been initialized for the analysis of the given model.

$\begin{array}{ll}\text { Youngs Modulus: } & 81 \mathrm{GPa} \\ \text { Poissons Ratio: } & 0.26 \\ \text { Density: } & 7100 \mathrm{Kg} / \mathrm{M}^{\wedge} 3\end{array}$


Tensile Strength:

$152 \mathrm{Mpa}$

Yield Strength (O.2\%): $\quad 98 \mathrm{MPa}$

Fatigue Endurance Limi: $\quad 68.94 \mathrm{MPa}$

Operating speed of pulley $=2000 \mathrm{rpm}(25 \%$ marginal speed is considered for load fluctuation $)$, Therefore, simulation is done for $1500 \mathrm{rpm}, 2000 \mathrm{rpm}, 2500 \mathrm{rpm}$.

\section{FATIGUE ANALYSIS OF PULLEY}

The fatigue analysis has been carried out by applying the give boundary conditions as per the specified geometry of the pulley.

\section{STATIC ANALYSIS OF PULLEY-400 AT 1500 RPM}

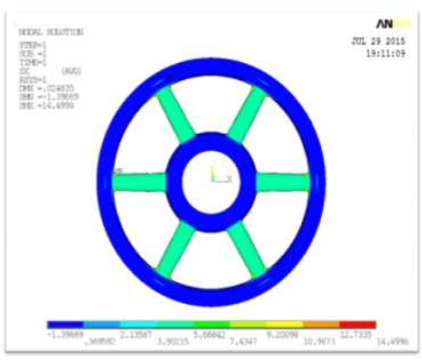

Figure 2: Radial Stress Plot

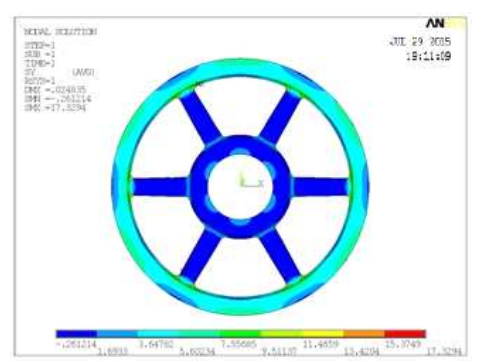

Figure 3: Hoop Stress Plot

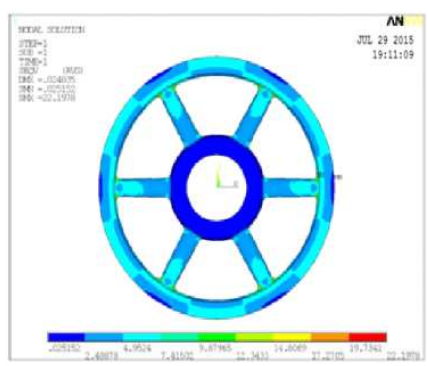

Figure 4: Von Mises Stress Plot

The radial stress of 14.49 $\mathrm{MPa}$, Hoop stress 17.32 MPa and Von Mises stress 22.19 MPa achieved from the analysis.

STATIC ANALYSIS OF PULLEY-400 AT 2000 RPM

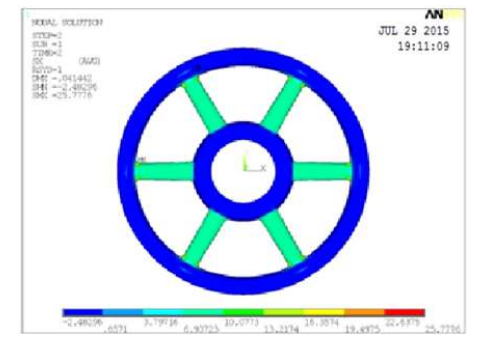

Figure 5: Radial Stress Plot

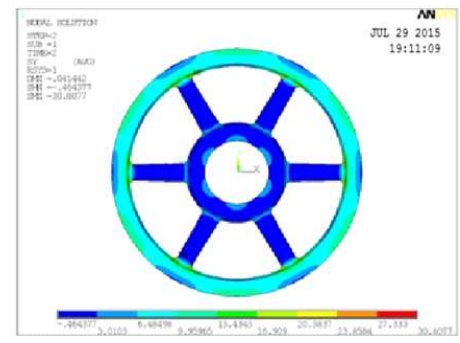

Figure 6: Hoop Stress Plot

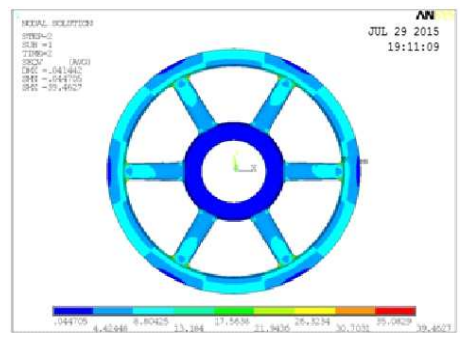

Figure 7: Von Mises Stress Plot

The radial stress of 22.77 $\mathrm{MPa}$, Hoop stress $30.8 \mathrm{MPa}$ and Von Mises stress $39.46 \mathrm{MPa}$ achieved from the analysis. 


\section{STATIC ANALYSIS OF PULLEY-400 AT 2500 RPM}

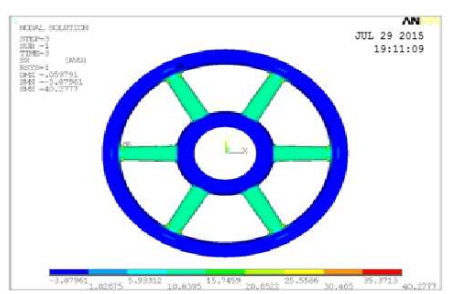

Figure 8: Radial Stress Plot

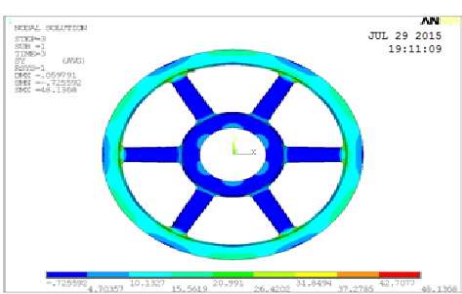

Figure 9: Hoop Stress Plot

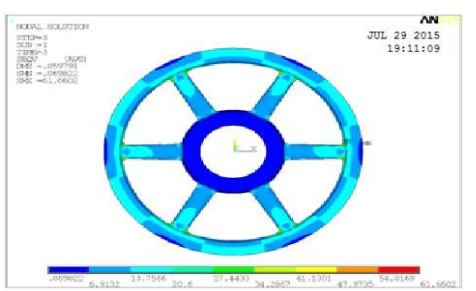

Figure 10: Von Mises Stress Plot

The radial stress of 40.27 MPa, Hoop stress 48.13 MPa and Von Mises stress 61.66 MPa achieved from the analysis. By the same procedure the static analysis of pulley -355 at 1500, 2000 and 2500 RPM has been carried out.

Table 1: Fatigue Analysis of Pulleys for different RPM

\begin{tabular}{|c|c|c|c|c|c|c|c|c|}
\hline PULLEY & RPM & $\begin{array}{l}\text { RADIAL } \\
\text { STRESS } \\
(\mathrm{Sx})-\mathrm{MPa}\end{array}$ & $\begin{array}{c}\text { HOOP } \\
\text { STRESS } \\
\text { (Sy) - Mpa }\end{array}$ & $\begin{array}{c}\text { VON-MISES } \\
\text { STRESS } \\
\text { (Seqv) - Mpa }\end{array}$ & $\begin{array}{l}\text { FOS= TENSILE } \\
\text { STRENGTH/Sy }\end{array}$ & $\begin{array}{c}\text { TENSILE } \\
\text { STRENGTH - } \\
\text { Mpa }\end{array}$ & $\begin{array}{c}\text { YIELD } \\
\text { STRENGTH- } \\
\text { Mpa }\end{array}$ & $\begin{array}{l}\text { ENDURANCE } \\
\text { LIMIT- Mpa }\end{array}$ \\
\hline \multirow{3}{*}{$\begin{array}{l}\text { PULLEY- } \\
400\end{array}$} & 1500 & 14.5 & 17.3 & 22.19 & 8.79 & \multirow{6}{*}{152} & \multirow{6}{*}{98} & \multirow{6}{*}{68.94} \\
\hline & 2000 & 25.77 & 30.8 & 39.46 & 4.94 & & & \\
\hline & 2500 & 40.27 & 48.13 & 61.66 & 3.16 & & & \\
\hline \multirow{3}{*}{$\begin{array}{l}\text { PULLEY- } \\
355\end{array}$} & 1500 & 10.82 & 14.98 & 18.39 & 10.15 & & & \\
\hline & 2000 & 19.25 & 26.64 & 32.7 & 5.71 & & & \\
\hline & 2500 & 30.08 & 41.64 & 51.1 & 3.65 & & & \\
\hline
\end{tabular}

According to Goodman theory the results can be validatd.

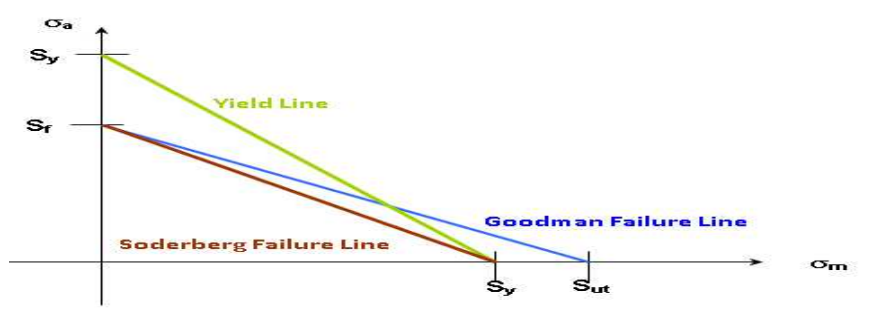

\section{Graph 1: Goodman Line}

\section{RESULTS AND DISCUSSION}

Graph 2: Stress plot with Goodman line

- From the analysis at all speed, the stress value is less than endurance limit value.The working stress falls in the infinite region

\section{CONCLUSIONS}

Fatigue evaluation is done at 4 points as shown in adjacent. These 4 points are subjected to max. Stress as compared to other places, Fatigue is evaluated for two combinations of load cases.

Event $1=1500 \mathrm{rpm}+2000 \mathrm{rpm}$

Event 2= 2000rpm+25000rpm

No. of cycles, the pulley subjected in each event is assumed, is 5000 cycles.

(Which means 1 cycle = start-up and shut-down of pulley operation) 
Event $1=1500 \mathrm{rpm}+2000 \mathrm{rpm}$

The combination of load at $1500 \mathrm{rpm}$ and $2000 \mathrm{rpm}$ produces an alternating stress intensity.

- At location $1=6.71 \mathrm{~N} / \mathrm{mm}^{\wedge} 2$

- At location $2=1.81 \mathrm{~N} / \mathrm{mm}^{\wedge} 2$

- At location $3=0.86 \mathrm{~N} / \mathrm{mm}^{\wedge} 2$

- At location $4=1.28 \mathrm{~N} / \mathrm{mm}^{\wedge} 2$

The pulley is subjected to 5000 cycles, while from the S-N Table,

The maximum number of cycles allowed at that stress intensity is $1 \mathrm{e} 6$.

\section{REFERENCES}

1. Shigley, J. E. Budynas, R.G., and Mischke, C.R., “Mechanical Engineering Design”, McGraw-Hill, pp.868-876, 2004.

2. Hwang, B., Lee, H., Jang., and Joo, I., “A Study of Stress Distribution of a Pulley for Automobile Static Load Condition', Proc. of Korean Society of Automotive Engineers Autumn Conference, vol.2,pp.1180-1184,2003.

3. Mohammed Abbas F \& Gopi Krishna, Modeling and Finite Element Analysis of a Walking Robot Leg Mechanism at High Speeds Using Adams Software, International Journal of Mechanical and Production Engineering Research and Development (IJMPERD), Volume 5, Issue 4, July - August 2015, pp. 105-114

4. Devendra Kumar, R.K. Mandloi “Analysis \& Prospects of Modification in Belt Conveyors - A Review” IJERA Vol. 3, Issue 1, January -February 2013, pp.581-587.

5. Ashwani Sharma \& M. A. Murtaza, Modeling and Finite Element Analysis of Vertical Axis Wind Turbine Rotor Configurations, International Journal of Mechanical and Production Engineering Research and Development (IJMPERD), Volume 6, Issue 3, May - Jun 2016, pp. 23-34

6. VINOD M. BANSODE, ABHAY A. UTPAT “Fatigue Life Prediction of A Butt Weld Joint In A Drum Pulley Assembly Using Non-Linear Static Structural Analysis” Dept. of Mechanical Engineering, College of Engineering, Pandharpur, India. 